\section{Injecting drug users who are (un)aware of their HIV serostatus: findings from the multi-center study AjUDE-Brasil II}

\author{
Usuários de drogas injetáveis que (des)conhecem \\ seu status sorológico para a infecção pelo HIV: \\ achados do Projeto AjUDE-Brasil II
}

Aline Dayrell Ferreira 1 Waleska Teixeira Caiaffa ${ }^{1}$ Francisco I. Bastos 2 Sueli Aparecida Mingoti 3 Projeto AjUDE-Brasil II 4

\section{Introduction}

1 Faculdade de Medicina Universidade Federal de Minas Gerais, Belo Horizonte, Brasil.

2 Centro de Informação Científica e Tecnológica, Fundação Oswaldo Cruz, Rio de Janeiro, Brasil. 3 Instituto de Ciências Exatas, Universidade Federal de Minas Gerais, Belo Horizonte, Brasil. 4 Other members listed at the end of the paper.

Correspondence W. T. Caiaffa Faculdade de Medicina Universidade Federal de Minas Gerais. Av. Alfredo Balena 190 Belo Horizonte, $M G$ 30130-100, Brasil. wcaiaffa@medicina.ufmg.br

\begin{abstract}
This study aimed to characterize the profiles of
Abstract injecting drug users (IDUs) who were unaware of their HIV serostatus, given the importance of this information for prevention strategies, especially in this vulnerable population, key to the HIVIAIDS dynamic. As part of a cross-sectional multi-city survey, IDUs were interviewed and HIV-tested by the ELISA technique. IDUs were categorized according to knowledge of their own HIV status as either aware or unaware. Means, averages, and proportions were compared between the groups using bi-and multivariate analyses. Of 857 IDUs interviewed, 34.2\% were unaware of their HIV serostatus. Those who were unaware were more likely: to have been recruited at sites where the HIV prevalence rate was considered medium ( $>10$ to $50 \%$; odds ratio $=$ 8.0) or high (> 50\%; 4.0); to be illiterate $(O R=$ 4.54); to have no prior HIV test ( $O R=2.22)$; to be male $(O R=1.81)$; and to have been enrolled more recently in syringe-exchange programs $(O R=1.69) . H I V$ prevention programs should target both individuals at risk and HIV-positive individuals. Programs to expand access to HIV testing are pivotal and should be tailored to specific contexts and populations.
\end{abstract}

AIDS Serodiagnosis; Intravenous Substance Abuse; Acquired Immunodeficiency Syndrome; HIV
Public health strategies have been developed to increase awareness of HIV serostatus among individuals and populations for the control of the HIV/AIDS epidemic. Knowledge of one's serostatus, expressed as early diagnosis of HIV infection, can allow adequate access to treatment, ensuring better response to therapy and quality of life among persons with HIV as well as reduction in AIDS mortality 1 . In addition, it is believed that such awareness is associated with lower frequency of practices that expose individuals to the risk of being (re)infected and of transmitting the virus $2,3,4,5,6$. Testing, counseling, and returning the test results thus has an effect on the epidemic's dynamics by reducing the frequency of risk interactions and HIV transmission 2,3,4.

Statistics indicate 40 million individuals infected worldwide 7 , with 600 thousand infected in Brazil 8 . Of these, an estimated $67 \%$ are unaware of their HIV serostatus 8 .

Based on this scenario and studies emphasizing the advantages of serostatus awareness, since the late 1980s the Brazilian Ministry of Health has invested in the creation of Anonymous Testing Centers (ATCs) or Centers for Serological Support and Orientation, characterized by free access, voluntary participation, and confidentiality, offering HIV testing along with pre- and post-test counseling ${ }^{2}$. In addi- 
tion to the availability of these centers, campaigns like Fique Sabendo! (Know it!) have also been developed. This campaign was launched in 2003 and aims to raise the Brazilian population's awareness concerning the importance of HIV testing, with the goal of a $150 \%$ increase in the number of tests performed in the country by 20068 .

The epidemiological profile of HIV/AIDS infection in Brazil is known to be differentiated, varying according to the period analyzed, exposure categories, and regional characteristics. Among the exposure categories, the most relevant is "heterosexual", followed by "injecting drug user" (IDUs), accounting for $19.1 \%$ of the AIDS cases diagnosed as of 20049 .

However, the proportional participation of IDUs varies substantially between regions, corresponding to some $60 \%$ of the AIDS cases reported in the South of the country $7,10,11$. IDUs play an even more relevant role in the HIV/ AIDS dynamics when considering the risk of transmission from infected IDUs to their sex partners and offspring 11 . Thus, injecting drug use behaviors such as initiation of use, sharing of injecting materials, and type of drug used have contributed to the spread of HIV and maintenance of the epidemic in Brazil 12.

The present study aims to characterize the profile of Brazilian IDUs who are unaware (versus aware) of their HIV serostatus, using data from the AjUDE-Brasil II Project. This line of analysis was allowed by the range of information included in the project and is especially relevant because of the lack of quantitative analyses on the choice to test for HIV infection in specific populations in the country. The resulting information can support public policies for testing and counseling, fostering awarenessraising strategies and contributing to greater effectiveness in the interventions to control the HIV/AIDS epidemic in Brazil.

\section{Methods}

The AjUDE-Brasil II Project was designed to assess the effectiveness of harm reduction strategies and establish the baseline situation of IDUs participating in syringe-exchange projects (SEP). This was a cross-sectional, multi-center study obtaining information on aspects related to this population. Participating IDUs were accessed by the SEP in six Brazilian cities (Porto Alegre and Gravataí in the State of Rio Grande do Sul, São José do Rio Preto in São Paulo, Itajaí and Florianópolis in Santa Catarina, and Salvador in Bahia) in 2000-2001. Selection of these
SEP was based on level of structuring and time in operation, on the epidemiological profile of the HIV/AIDS epidemic, and the pattern and forms of drug consumption in the different sites.

The project included face-a-face interviews conducted by previously trained health agents, using a standardized structured questionnaire, focusing on socio-demographic aspects, living conditions, drug use, risk practices, sexual behavior, knowledge on blood-borne infections / diseases and utilization of health services, including HIV testing 13.

In addition, blood sample was taken on filter paper for diagnosis by ELISA (enzyme-linked immunosorbent assay) of HIV and other bloodborne and/or sexually transmitted infections, according to the methodology described in the document systematizing the AjUDE-Brasil I procedures 13 .

In all stages of the study, procedures were performed to guarantee the data quality and reliability 13 .

\section{Study sample}

IDUs 18 years of age or older and with a history of injecting use in the five years prior to the interview were accessed and recruited by outreach workers in each site. A total of 857 IDUs participated in the study, and no refusals were recorded.

The current study adopted the calculation referring to the detection power for the sample calculation from the source project 13 . Based on testing the hypothesis of comparing proportions and an alpha error of $5 \%$, we observed a power of $90 \% 14$.

The premise was that $56.6 \%$ of IDUs were unaware of their serostatus based on data obtained during the AjUDE-Brasil I Project, defining serostatus unawareness as infected IDUs who had never had an HIV test or had never returned for the test results 13

\section{Variables}

Knowledge of HIV serostatus was defined as the outcome, with the IDUs classified in two groups. The first consisted of IDUs who were unaware of their serostatus, including: (a) HIVpositive IDUs, based on findings from field testing and who either reported during the interview that they were unaware of their serostatus or claimed to be HIV-negative and (b) HIVnegative IDUs who reported not knowing their serostatus or claimed to be HIV-positive. The other IDUs, i.e., those who were consistently aware of their serostatus in accordance with 
the empirical test findings, were defined as those who were actually aware of their HIV status.

Among the covariables was "local HIV background prevalence among IDUs", a socio-demographic variable obtained from classification of the SEP where the participants were recruited, in terms of overall HIV prevalence, based on criteria set by the World Health Organization 15. A "low seroprevalence site" was defined as one where the mean prevalence was less than $10 \%$, which in this case included only one SEP, where the overall HIV prevalence among IDUs was $6.4 \%$. Four SEP, with background HIV prevalence varying from 30.9 to $38.3 \%$, were grouped as "medium prevalence sites", and finally one SEP where $64.3 \%$ of the IDUs were HIV-positive was classified as a "high prevalence site".

Health services utilization was analyzed according to the following variables: (1) "lifetime treatment seeking at health services"; (2) "utilization of SEP”, referring to IDUs who reported using or having used the services in such projects; (3) "time using SEP", related to the time elapsed between the first contact with the SEP and the last recorded contact or the time of the interview (in the case of actively engaged IDUs); (4) "interest in having an HIV test", as indicated by the question "Have you ever considered having an HIV test?" and; (5) "prior HIV test", as reported by the IDUs.

Analysis of knowledge about infections was based on the questions: "Do you know of any blood-transmitted disease or infection?", "Do you know ways of preventing HIV infection?", among others.

Analysis of drug use considered information from the six months prior to the interview, and needle/syringe sharing was defined as selfreported lending or borrowing of previously used injecting equipment (active or receptive sharing).

Sexual relations were characterized according to the nature of the partnership, either occasional or regular. Male condom use was defined as consistent when the interviewee reported using condoms in all sexual relations in the six months prior to the interview.

\section{Analysis}

The study analyzed frequency distributions, central tendency and dispersion, comparison of means and proportions using respectively the Student's t and chi-squared tests.

The association between the outcome and the covariables was explored, allowing the se- lection of variables $(p \leq 0.25)$ to construct the multivariate model. Odds ratios (OR) were used to measure the associations and respective $95 \%$ confidence intervals (95\%CI).

The relevance of each variable included in the multivariate model was verified by the Wald statistic, having removed those that did not contribute significantly. Adjustment of the final model was verified by the Hosmer and Lemeshow test. The final model contained variables with statistical significance $(\mathrm{p} \leq 0.05)$ and biological plausibility 16 . Based on the estimators obtained by logistic regression, the probability of the event's occurrence was calculated 16. The analyses were performed using Microsoft Excel, version 2000, and SPSS, version 11.5.

\section{Ethical issues}

The IDUs participating in AjUDE-Brasil II signed a free informed consent form in accordance with Ministry of Health Ruling 196/96. The project was approved by the Research Ethics Committee of the Universidade Federal de Minas Gerais (case ETIC168/99).

\section{Results}

Of the 857 interviewees, $34.2 \%$ were unaware of their HIV serostatus (according to the classification adopted by this study), of whom $39.9 \%$ were HIV-positive. The overall HIV prevalence was $36.5 \%$, but only $28.9 \%$ reported being HIVpositive. The IDUs were predominantly male (82.9\%), with a mean age of $28.5 \pm 8.2$ years. The majority of the IDUs reported having used SEP services some time in life, with a mean utilization of 11.6 \pm 14.5 months (median $=5.9$ months). Some three-fourths of the interviewees had considered having an HIV test, but only $47.8 \%$ had actually been tested. Among the IDUs who had been tested previously, $20 \%$ had not returned for the results (Figure 1, Table 1).

Stratifying the IDUs by recruitment site (Table 1) shows that lack of awareness of one's serostatus varied from 14.9 to $46.1 \%$ and was higher in sites with medium background HIV prevalence. In all the sites there was a lower proportion of IDUs who reported being HIV-positive as compared to the actual proportion of infected IDUs (as defined by the field testing results).

There were a high proportion of males, with no significant gender difference between sites. However, there was a significant age difference, with younger participants recruited predominantly from low-prevalence sites (median = 24.5 years). As for utilization of SEP services, 
Figure 1

Classification of IDUs according to knowledge of HIV status. AjUDE-Brasil II Project, 2000-2001.

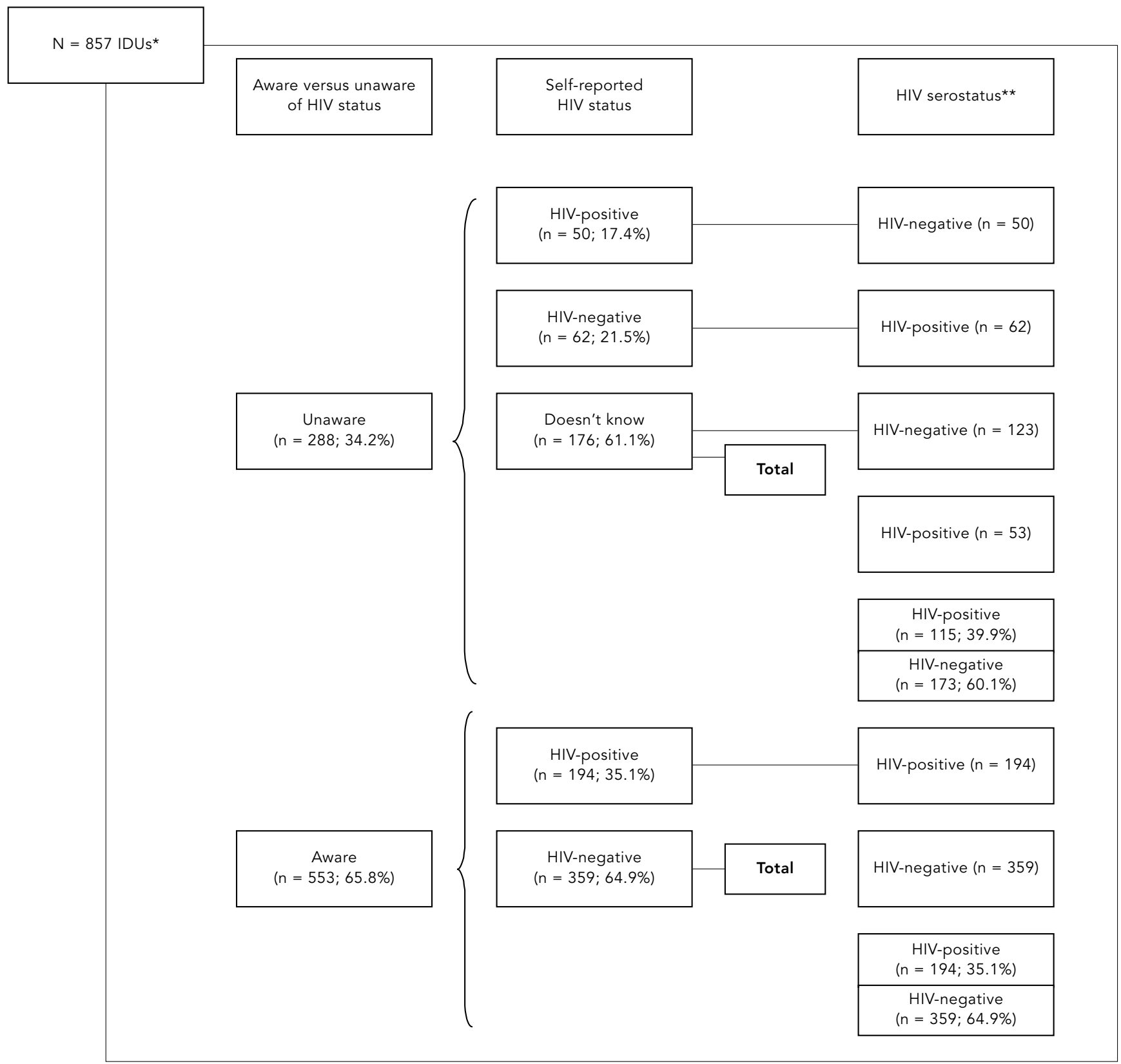

* Totals may vary due to missing/inchoate answers;

** Defined by two ELISA tests on eluted blood (filter paper). 
Profile of injecting drug users according to selected characteristics. AjUDE-Brasil II Project, 2000-2001.

\begin{tabular}{|c|c|c|c|c|c|}
\hline \multirow[t]{2}{*}{ Characteristics } & \multirow[t]{2}{*}{ Total $(\mathrm{n}=857)$} & \multicolumn{3}{|c|}{ Local HIV prevalence among IDUs } & \multirow[t]{2}{*}{$\mathrm{p}$ value } \\
\hline & & $\begin{array}{c}\text { Low } \\
(n=203)\end{array}$ & $\begin{array}{l}\text { Medium } \\
(n=399)\end{array}$ & $\begin{array}{c}\text { High } \\
(n=255)\end{array}$ & \\
\hline \multicolumn{6}{|l|}{ HIV serostatus (n [\%]) } \\
\hline Unaware of HIV status & $288[34.2]$ & 30 [14.9] & $179[46.1]$ & 79 [31.5] & $<0.01$ \\
\hline HIV-positive status (self-reported) & 244 [28.9] & $11[5.4]$ & $112[28.9]$ & $121[48.0]$ & $<0.01$ \\
\hline HIV-positive status (ELISA) & $311[36.5]$ & $13[6.4]$ & $136[34.1]$ & $162[64.3]$ & $<0.01$ \\
\hline \multicolumn{6}{|l|}{ Gender (n [\%]) } \\
\hline Male & 709 [82.9] & $176[86.7]$ & $327[82.4]$ & $206[80.8]$ & 0.23 \\
\hline \multicolumn{6}{|l|}{ Age (years) } \\
\hline Mean \pm SD & $28.5 \pm 8.2$ & $25.7 \pm 6.5$ & $28.0 \pm 8.2$ & $31.4 \pm 8.6$ & $<0.01$ \\
\hline Median & 27.0 & 24.5 & 27.0 & 30.0 & \\
\hline \multicolumn{6}{|l|}{ Use of SEP } \\
\hline Lifetime use (n [\%]) & $600[70.3]$ & $135[66.8]$ & $300[75.8]$ & $165[64.7]$ & 0.005 \\
\hline \multicolumn{6}{|l|}{ Time used (months) } \\
\hline Mean \pm SD & $11.6 \pm 14.5$ & $12.7 \pm 16.2$ & $10.4 \pm 11.5$ & $12.6 \pm 17.0$ & 0.084 \\
\hline Median & 5.9 & 5.9 & 6.7 & 3.0 & \\
\hline \multicolumn{6}{|l|}{ Lifetime HIV testing } \\
\hline Considered having test (n [\%]) & $646[75.6]$ & $137[67.5]$ & $286[71.7]$ & $223[88.1]$ & $<0.01$ \\
\hline Had test (n [\%]) & $407[47.8]$ & $58[28.7]$ & $189[47.6]$ & $160[63.2]$ & $<0.01$ \\
\hline \multicolumn{6}{|l|}{ Times tested } \\
\hline Mean \pm SD & $1.1+1.9$ & $1.6+0.9$ & $2.6+2.4$ & $2.6+2.2$ & 0.003 \\
\hline Median & 0.0 & 1.0 & 2.0 & 2.0 & \\
\hline Returned for result (n [\%]) & $317[85.2]$ & $31[54.4]$ & $147[86.5]$ & $139[95.9]$ & $<0.01$ \\
\hline
\end{tabular}

the IDUs from medium prevalence sites reported using these services more frequently (75.8\%), however they had used them for less time (mean $=10.4 \pm 11.5$ months).

As for HIV testing, in contexts with low background prevalence, a significant difference was observed when comparing IDUs who reported having considered an HIV test $(67.5 \%)$ with IDUs who had actually had the test (28.7\%). HIV testing was more frequent in high-prevalence sites (63.2\%), and a higher proportion also returned to obtain the results $(93.8 \%)$.

Comparing IDUs stratified according to awareness of HIV serostatus, Table 2 shows that IDUs recruited by SEP from sites with a background HIV prevalence greater than $10 \%$ had two to four times higher likelihood of not knowing their serostatus as compared to the other IDUs. Lack of awareness of serostatus by IDUs was also significantly higher among male IDUs $(\mathrm{OR}=1.7 ; 95 \% \mathrm{CI}: 1.1-2.6)$, whites $(\mathrm{OR}=1.4$; 95\%CI: 1.1-1.9), and those who reported some religion $(\mathrm{OR}=1.5$; 95\%CI: $1.0-2.1)$.
As for work status and schooling, recently unemployed IDUs and those who had never taking technical or occupational training showed increased odds of not knowing their HIV serostatus (OR $=1.5$; 95\%CI: 1.1-2.2; $\mathrm{OR}=$ 1.5; 95\%CI: 1.1-2.0, respectively). IDUs with less schooling showed higher odds of not knowing their serostatus, as shown by comparing those with no schooling and those who had finished at least the eighth grade $(\mathrm{OR}=3.8$; 95\%CI: 1.6-9.3).

Lack of use of SEP and health services as well as shorter use of SEP services were associated both with unawareness of serostatus and lack of HIV testing. As expected, unawareness of serostatus was more common among IDUs who had never considered being tested $(\mathrm{OR}=$ 1.5; 95\%CI: 1.1-2.1) or had never actually been tested $(\mathrm{OR}=2.3$; 95\%CI: 1.7-3.1). Identification of aspects related to infection and/or bloodborne diseases, such as knowing ways to prevent HIV transmission, proved to be a protective factor against unawareness of serostatus 
Bivariate analysis of aspects associated with unawareness of one's HIV serostatus. AjUDE-Brasil II Project, $2000-2001$.

\begin{tabular}{|c|c|c|c|c|}
\hline Variables & $\mathbf{N}$ & Unaware* $(\%)$ & OR & $95 \% \mathrm{Cl}$ \\
\hline \multicolumn{5}{|l|}{ Socio-demographic } \\
\hline \multicolumn{5}{|l|}{ Local HIV prevalence among IDUs } \\
\hline $\operatorname{Low}(<10 \%)$ & 202 & 14.9 & 1.00 & \\
\hline Medium (10-50\%) & 388 & 46.1 & 4.91 & $3.18-7.60$ \\
\hline High (>50\%) & 251 & 31.5 & 2.63 & $1.65-4.22$ \\
\hline Male gender & 698 & 36.0 & 1.70 & $1.13-2.57$ \\
\hline White skin color & 388 & 38.4 & 1.41 & $1.06-1.88$ \\
\hline Having a religion & 639 & 36.0 & 1.47 & $1.03-2.09$ \\
\hline Unemployed** & 620 & 36.5 & 1.52 & $1.07-2.16$ \\
\hline Having completed a technical course & 343 & 36.9 & 1.47 & $1.08-2.00$ \\
\hline \multicolumn{5}{|l|}{ Schooling } \\
\hline None & 29 & 51.7 & 3.81 & $1.55-9.34$ \\
\hline$\leq 4^{\text {th }}$ grade & 246 & 41.1 & 2.48 & $1.39-4.43$ \\
\hline $5^{\text {th }}$ to 8 th grade & 441 & 31.3 & 1.62 & $0.93-2.84$ \\
\hline$>8^{\text {th }}$ grade & 82 & 22.0 & 1.00 & \\
\hline \multicolumn{5}{|l|}{ Use of SEP and health services } \\
\hline Never used SEP & 247 & 38.5 & 1.32 & $0.97-1.79$ \\
\hline Time of SEP use $\mathrm{u}^{\star \star \star} \leq 5.9$ months & 399 & 38.8 & 1.53 & $1.14-2.05$ \\
\hline Never had health treatment & 215 & 50.2 & 2.54 & $1.84-3.49$ \\
\hline \multicolumn{5}{|l|}{ HIV testing } \\
\hline Never considered testing & 201 & 41.3 & 1.49 & $1.08-2.07$ \\
\hline Never tested & 433 & 43.2 & 2.29 & $1.70-3.07$ \\
\hline HIV + and doesn't treat & 153 & 28.8 & 3.23 & $1.53-6.80$ \\
\hline \multicolumn{5}{|l|}{ Knowledge } \\
\hline About blood-borne infections & 716 & 33.1 & 0.74 & $0.50-1.10$ \\
\hline About HIV/AIDS & 777 & 32.9 & 0.53 & $0.31-0.89$ \\
\hline Knows some HIV carrier & 609 & 36.3 & 1.45 & $1.04-2.04$ \\
\hline \multicolumn{5}{|l|}{ Drug use } \\
\hline IDU $<3$ years & 185 & 38.4 & 1.29 & $0.92-1.81$ \\
\hline Smoking ${ }^{\star \star}$ & 678 & 36.7 & 1.87 & $1.27-2.86$ \\
\hline Obtains needles from friend** & 161 & 39.1 & 1.28 & $0.90-1.82$ \\
\hline Shares needles ${ }^{\star \star}$ & 161 & 42.2 & 1.52 & $1.06-2.17$ \\
\hline Cleaning of needles/syringes ${ }^{\star \star}$ & 296 & 39.5 & 1.41 & $1.05-1.89$ \\
\hline \multicolumn{5}{|l|}{ Regular sex partners ${ }^{\star \star, \#}$} \\
\hline Not reported & 189 & 38.6 & 3.78 & $1.07-13.27$ \\
\hline Partners use drugs & 103 & 37.9 & 1.37 & $0.88-2.17$ \\
\hline $100 \%$ condom use & 134 & 22.4 & 0.50 & $0.32-0.79$ \\
\hline \multicolumn{5}{|l|}{ Occasional sex partners ${ }^{\star \star}, \#$} \\
\hline Sex for drugs & 58 & 37.9 & 1.85 & $0.87-2.78$ \\
\hline $100 \%$ condom use & 186 & 18.3 & 0.30 & $0.19-0.48$ \\
\hline
\end{tabular}

* IDUs classified in this study as those who were unaware of their HIV serostatus:

** Data refer to the six months prior to the interview;

*** Cutoff based on median time using SEP services;

\# Sexual relations with partners of the opposite sex. 
$(\mathrm{OR}=0.5$; 95\%CI: 0.3-0.9). On the other hand, IDUs who were unaware of their serostatus were more likely to have persons with HIV in their social networks (OR = 1.5; 95\%CI: 1.1-2.0).

The groups were different as to risk behaviors for infection/disease in relation to sharing needles/syringes (OR = 1.5; 95\%CI: 1.1-2.2) and inadequate cleaning of injecting equipment for subsequent use $(\mathrm{OR}=1.4 ; 95 \% \mathrm{CI}$ : 1.1-1.9). As for sexual behaviors, not having relations with regular partners of the opposite sex was associated with increased odds of not knowing one's serostatus $(\mathrm{OR}=3.8$; 95\%CI: 1.1-13.3). Inversely, there was an association between consistent condom use in all sexual relations with persons of the opposite sex in the last six months and more accurate knowledge of serostatus, and the association was shown for sexual relations both with regular partners $(\mathrm{OR}=0.5$; 95\%CI: $0.3-0.8)$ and occasional ones ( $\mathrm{OR}=0.3$; 95\%CI: $0.2-0.5)$.

Table 3 presents the results of the multivariate analysis. The variables that best explain unawareness of HIV serostatus were: "site where IDU was recruited"; "gender"; "schooling"; "time using SEP services”, and "lifetime HIV testing”.

Comparing individuals from sites with low background HIV prevalence and those recruited from medium prevalence sites, the latter were more likely not to know their serostatus $(\mathrm{OR}=$ 8.0; 95\%CI: 4.8-13.3). The odds were also increased, but to a lesser degree, among individuals from high-prevalence sites as compared to the reference category $(\mathrm{OR}=4.0 ; 95 \% \mathrm{CI}: 2.3-7.0)$.

In addition, unawareness of serostatus showed increased odds in male IDUs (OR $=1.8$; 95\%CI: 1.1-2.9), those who had been in contact with an SEP for less time (OR = 1.7; 95\%CI: 1.22.4), and those who had never been tested for HIV (OR $=2.2$; 95\%CI: 1.6-3.2). As for schooling, there was a dose-response gradient in the association with unawareness of serostatus: IDUs who had never studied shower higher odds of not knowing (OR $=4.5$; 95\%CI: 1.6 12.7), with progressively weaker associations for those who had studied up to the fourth grade $(\mathrm{OR}=2.5$; 95\%CI: $1.3-4.9)$ and those had studied from the fourth to eighth grades (OR = 1.7; 95\%CI: 0.9-3.1), as compared to those with more than eight years of schooling.

Calculating the probability of the logistic regression estimators shows that IDUs recruited from medium background HIV prevalence sites, males, those who had never studied, those with less contact with an SEP, and those who reported never having been tested for HIV showed a 0.53 probability of not knowing their HIV status. Meanwhile, IDUs from low background HIV prevalence sites, females, those

\begin{tabular}{|c|c|c|}
\hline \multicolumn{3}{|c|}{$\begin{array}{l}\text { Multivariate logistic regression using unawareness of HIV serostatus } \\
\text { as the response variable. }\end{array}$} \\
\hline Variables & $\begin{array}{l}\text { Crude OR } \\
(95 \% \mathrm{Cl})\end{array}$ & $\begin{array}{l}\text { Adjusted OR } \\
\qquad(95 \% \mathrm{Cl})\end{array}$ \\
\hline \multicolumn{3}{|c|}{ Local HIV prevalence in IDUs } \\
\hline Low & 1.00 & 1.00 \\
\hline High & $2.63(1.65-4.22)$ & $4.04(2.32-7.03)$ \\
\hline Medium & $4.91(3.18-7.60)$ & $8.00(4.81-13.28)$ \\
\hline \multicolumn{3}{|l|}{ Gender } \\
\hline Female & 1.00 & 1.00 \\
\hline Male & $1.70(1.13-2.57)$ & $1.81(1.13-2.90)$ \\
\hline \multicolumn{3}{|l|}{ Time of SEP use } \\
\hline$>5.9$ months & 1.00 & 1.00 \\
\hline$<5.9$ months & $1.53(1.14-2.05)$ & $1.69(1.20-2.38)$ \\
\hline \multicolumn{3}{|c|}{ Lifetime HIV testing } \\
\hline Yes & 1.00 & 1.00 \\
\hline No & $2.29(1.70-3.07)$ & $2.22(1.55-3.16)$ \\
\hline \multicolumn{3}{|l|}{ Schooling } \\
\hline None & $3.81(1.55-9.34)$ & $4.54(1.62-12.71)$ \\
\hline$\leq 4$ th grade & $2.48(1.39-4.43)$ & $2.50(1.29-4.85)$ \\
\hline 5 th to 8 th grade & $1.62(0.93-2.84)$ & $1.66(0.88-3.12)$ \\
\hline$>8^{\text {th }}$ grade & 1.00 & 1.00 \\
\hline
\end{tabular}

who had finished at least the eighth grade, those using a harm reduction program for more than 5.9 months, and those who had been tested for HIV showed only a 0.005 probability of not knowing their serostatus (Figure 2).

\section{Discussion}

This study showed that a significant proportion of IDUs are unaware of their HIV status. Among these, during the survey some $40 \%$ were diagnosed as HIV-positive, highlighting the major spread of the virus in the study population as a consequence of different risk attitudes and behaviors, including lack of care for one's own health. In addition to lack of HIV testing, unawareness of serostatus was associated with the characteristics of IDUs recruiting sites, low schooling, less contact with harm reduction programs, and male gender.

Unawareness of serostatus was observed with a quite variable frequency, with a heavy contextual influence in addition to individual variations, which the study also explored. Few studies have approached this issue, thus hin- 


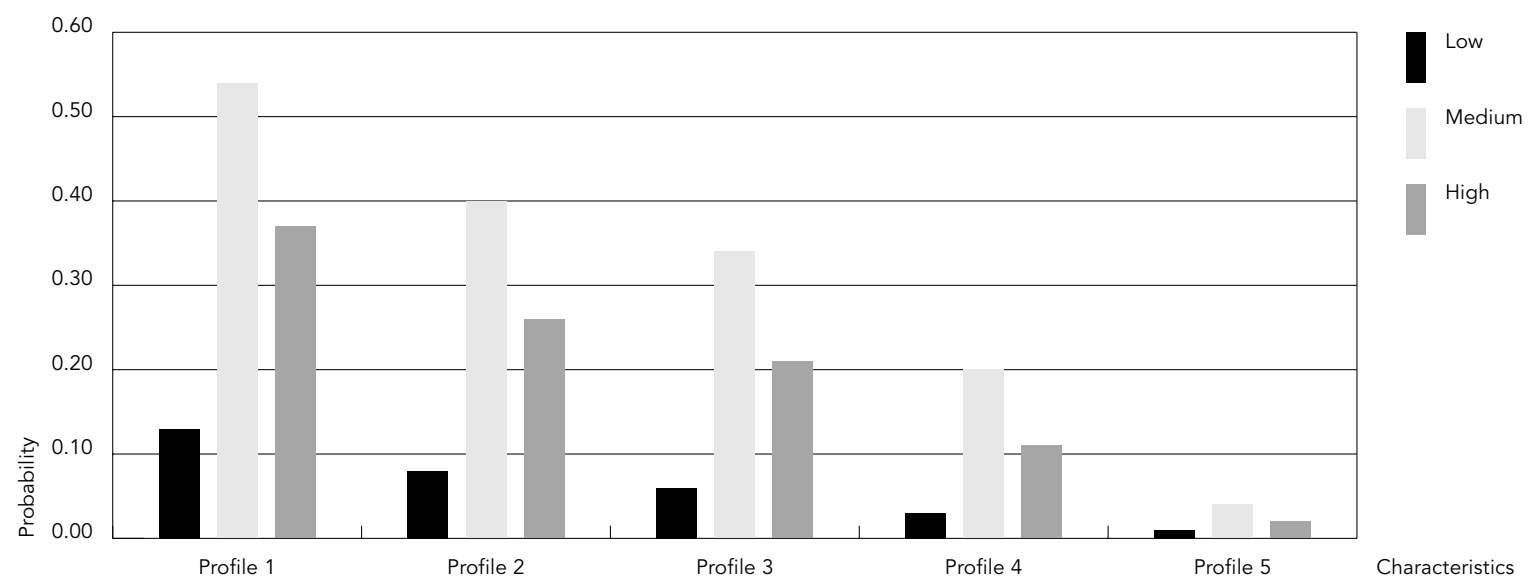

Profile 1: Male IDU, no schooling, has used SEP for $\leq 5.9$ months, and never tested.

Profile 2: Male IDU, no schooling, has used SEP for $>5.9$ months, and never tested.

Profile 3: Male IDU, no schooling, has used SEP for $\leq 5.9$ months, and already tested.

Profile 4: Male IDU, studied $>8^{\text {th }}$ grade, has used SEP for $\leq 5.9$ months, and never tested.

Profile 5: Female IDU, studied $>8$ th grade, has used SEP for $>5.9$ months, and already tested.

dering comparisons. However, a recent study in San Francisco, California, from 1997 to 1999 showed similar proportions of unawareness of serostatus $(43.7 \%)$, although using a different definition for the outcome, namely IDUs who had not HIV-tested or who did not inform the results of their HIV tests during the interview 17.

Some comparisons can be made using estimated proportions of individuals who are unaware of their HIV serostatus, considering different contexts. For example, in Brazil an estimated $66.7 \%$ of HIV-infected individuals are unaware of their condition 8 , which is a higher proportion than in the current study. In the United States, unawareness of serostatus (approximately $25 \%$ ) appears to be much less frequent as compared to either the overall Brazilian estimate or the findings from the current study 18 . The differences in these proportions between the two countries and the population studied here may be related to the HIV prevalence in the resident populations and the peculiar characteristics of IDUs, among other factors.

The milieu to which the individual belongs, expressed here in simplified form by HIV seroprevalence among one's peers, can influence attitudes, habits, and beliefs. According to data from the Behavioral Risk Factor Surveillance System (BRFSS), individuals living in neighborhoods where HIV is more prevalent tend to be tested more frequently 19 , probably since they are more familiar with issues related to both the infection and the clinical syndrome 20 .

The current study highlighted both the different proportions of serostatus awareness and differences in aspects related to HIV testing according to each specific context, with higher proportions of testing in high-prevalence neighborhoods.

International studies in different vulnerable populations have shown higher testing proportions than in the current study, thus highlighting the importance of expanding testing, counseling, and returning test results in the Brazilian context. In a study in Baltimore with 558 IDUs in 1999-2000, 84\% reported previous HIV testing 21. According to the HIV Testing Survey (HITS) in 1995-1996 (HITS-I) and 19981999 (HITS-II), more than $75 \%$ of the subjects had already been tested 3 .

In addition, individual characteristics of the study population can influence HIV testing, with an obvious impact on the serostatus unawareness rate.

Individuals with little schooling show higher odds of not being properly informed about issues related to HIV infection and AIDS and thus have an insufficient perception of the objective risks to which they are exposed 22,23 or express a fatalistic view, i.e., that nothing can 
be done to avoid HIV infection or AIDS 24. This limited knowledge along with fatalism and denial 25 can be expressed as less preoccupation with one's serostatus 20 .

This study showed an association (with a dose-response gradient) between low schooling and serostatus unawareness. Individuals with less schooling had higher odds of not knowing their HIV serological status. These findings are similar to those of Tobin et al. 21, who show an association between low schooling and lack of HIV testing among North American IDUs.

Unawareness of one's HIV status can be even more relevant in populations with low schooling, since a substantial proportion of this population is not tested, and when they do have the HIV test they fail to return to pick up the result 26. Sullivan et al. 26 identified IDUs as those who return the least frequently to pick up their results (27\%), as compared to other groups who are at particular risk for HIV infection. In the current study, approximately $20 \%$ of the IDUs who had been tested for HIV failed to return for the result, a figure that is probably underestimated, since it was measured indirectly by the questionnaire.

The reasons for "failure to return" for one's HIV test results have been discussed by various authors. Two important factors are fear of finding out that they are infected and discrimination associated with seropositive status 23,27 . Thus, the association shown by the current study between high local background HIV prevalence and higher individual probability of having been tested does not allow one to generalize, i.e., sites heavily affected by the epidemic are not necessarily associated with higher serostatus awareness. For example, in Africa, where HIV/AIDS prevalence is the highest in the world, individuals tend not to want to know their serostatus, because they believe that HIVpositive status is associated with social stigma and somber prospects as to the availability of appropriate treatment, thus contributing to the high proportion of individuals who are unaware of their serostatus in various African communities 28 . The recent expansion of antiretroviral treatment appears to have contributed to a reduction in stigma in some contexts, although the findings are still not conclusive 29 .

Analyzing the issue from an additional perspective, IDUs can display differentiated behaviors within the context of harm reduction programs. An example is the association between less use of SEP services and higher odds of not knowing one's HIV serostatus. This finding could highlight harm reduction activities as a vehicle for greater dissemination of information on infection/clinical evolution of HIV infection, as well as greater visibility and referral of IDUs to anonymous testing centers. In this sense, SEP utilization could encourage HIVtested IDUs to return for their test results, thus favoring an increase in the proportion of individuals who are actually aware of their HIV status 21.

Some variables that are amenable to differentiated intervention were also associated with serostatus unawareness, such as gender. Some specificities of the testing, counseling, and return for test results process are known to be frequently associated with socio-demographic and cultural characteristics. For example, studies have shown that individuals with incorrect information on HIV/AIDS, in addition to having low schooling, are mostly young 30,31 and male 22,31 . Thus, as observed in this study and the literature, women are generally more informed and are tested more frequently as compared to men, and thus have higher odds of knowing their HIV serostatus.

Risk practices for HIV infection 3,22,23,27,32,33 and recognition of increased risk 22 can increase the odds of individuals knowing their serological status. In this sense, another analysis in the AjUDE Project showed a higher frequency of risk behaviors among female IDUs, in relation to initiation in drug injecting and to sexual practices 34 , which on the other hand could favor HIV testing. In addition, women generally have higher odds of knowing their HIV status, due to specific programs for diagnosis during prenatal care and childbirth 1,33 .

Some other findings should not be overlooked. In relation to consistent condom use, an apparently inverse association was observed. As discussed above, individuals with more frequent risk practices tend to be tested more frequently and probably tend more to know their HIV status. However, the interviewees who reported consistent condom use, that is, apparently at reduced risk for infection, were more likely to know their serostatus. Still, since this was a cross-sectional study, this finding may express behavior changes subsequent to testing. An alternative interpretation would be that certain lifestyles and health precautions could be mediating both findings (condom use and testing). However, only an in-depth investigation in this area would be capable of elucidating this possibility 35 .

The study's cross-sectional design limits the interpretation of some findings, principally those related to a possible reverse causality. In addition, use of data collected for other purposes limits the important specific analyses in 
the characterization of HIV serostatus unawareness, for example, reasons leading to lack of concern over one's serostatus, not testing, and not returning for test results.

The study may have committed a bias by using non-random samples, with the possibility of a survival bias, recruiting IDUs in better health and consequently underestimating the true HIV seroprevalance in the study population. A recall bias may have occurred with a resulting underestimation in the data due to overvaluing of exposures, as well as an information bias in view of interviewee's conditions in the SEP context, which could favor "desirable" responses.

In addition, comparisons were limited by the lack of publications on unawareness of HIV infection status in keeping with this study's design and the reduced number of quantitative studies on HIV testing in IDUs.

Despite these limitations, the study produced relevant findings on knowledge of HIV serological status in the IDUs population. This question permeates the testing process and is associated with other equally relevant factors, like the context to which the individual belongs, expressed here by background HIV prevalence in each local context. IDUs with similar

\section{Resumo}

Este estudo busca caracterizar o perfil de usuários de drogas injetáveis (UDIs) que desconhecem seu status sorológico para a infecção pelo HIV, em virtude da importância desta população na dinâmica da epidemia de HIVIAIDS e do conhecimento da sorologia como estratégia preventiva. Foram analisadas informações do Projeto AjUDE-Brasil II, estudo seccional multicêntrico, obtidas mediante questionário e teste sorológico para diagnóstico do HIV (ELISA). Os UDIs foram agrupados em: (1) UDIs que desconheciam seu sorostatus para a infecção pelo HIV e (2) UDIs que o conheciam. Foram realizadas comparações de médias, medianas e proporções, análises bivariadas e multivariadas. Dos 857 UDIs, 34,2\% desconheciam sua sorologia. Estes apresentaram, significativamente, uma maior chance de terem sido recrutados de locais onde a prevalência do HIV era considerada média $(O R=8,0)$ e alta $(O R=$ $4,0)$; de serem do sexo masculino $(O R=1,8)$; de freqüentarem há menos tempo os programas de redução de danos $(O R=1,7)$, de nunca terem realizado o teste anti-HIV $(O R=2,2)$ e de nunca terem estudado $(O R=$ 4,5). Estratégias preventivas devem ser elaboradas visando aos diferentes fatores associados ao desconhecimento do status sorológico, principalmente levando em consideração o contexto em que o UDIs está inserido.

Sorodiagnóstico da AIDS; Uso Indevido de Drogas Parenterais; Síndrome de Imunodeficiência Adquirida; HIV characteristics displayed distinct probabilities of not knowing their HIV status, according to the areas where they were recruited. Preventive strategies should thus take the contextual dimension into account, formulating culturally appropriate interventions.

One can thus suppose that preventive campaigns will contribute to knowledge of serological status among IDUs, as long as they focus on information concerning the infection and disease and encourage testing. Such findings could also be used by anonymous testing centers, reinforcing the importance of pre-test counseling to reduce the rate of non-return for test results.

The findings also emphasize the importance of maintaining harm reduction programs and the need to focus in more detail on the issues approached here, such as testing and counseling, as well as referral and counter-referral between harm reduction programs and anonymous testing centers.

This study allowed developing a differentiated approach to the issue of HIV serostatus unawareness, not limited to prior HIV testing. Further research in this area is needed, given the relevance of such issues for controlling the HIV epidemic.

\section{Contributors}

A. D. Ferreira participated in all stages of the study, including the design, data analysis and interpretation, literature review, and drafting of the manuscript. W. T. Caiaffa, principal investigator of the AjUDE-Brasil Project, participated in all areas of the project and was responsible for the original idea, supervision of the analyzed data, and revision of the manuscript. F. I. Bastos participated in all phases of the study and was responsible for reviewing the manuscript, playing a key role in updating the bibliographic references. S. A. Mingoti assisted in the statistical analyses and calculations and is responsible for the statistical component of the AjUDE-Brasil II Project. The AjUDE-Brasil II Project was conducted in 2000-2001 by an extensive team, listed below. 


\section{Other members of the AjUDE-Brasil II Project}

J. Andrade, T. Andrade, A. Brás, R. T. Caiaffa, I. Cardoso, M. Cardoso, M. Cardoso, R. Carmosina, A. B. Carneiro-Proietti, K. Casseb, M. A. Chagas, R. Coelho, M. Colombo, M. Decândio, S. F. Deslandes, I. L. Dias, D. Dominguez, D. Doneda, R. Eller, E. Ferreira, D. Gandolfi, G. Gomes, T. Grever, A. Guimarães, P. Güths, M. Hacker, N. Januário, R. Junkes, R. Knoll, A. Lopes, D. Lisboa, M. Lopes, Â. Maia, M. Malta, R. Marinho, C. Martins, D. Matos, R. Mayer, S. Mello, H. Mendes, E. Mendonça, J. Moreira, A. C. Oliveira, D. Padilha, A. Paixão, I. Picinim, F. Proietti, P. Reis, C. Rinaldi, R. Rosa, V. Rodrigues, E. Santos, M. Santos, A. M. Silva, R. Silva, I. Silva, F. Silva, G. Strossi, M. Sudbrack, S. Tomaz, T. Telles, M. Urço, W. Vargas Jr.

\section{References}

1. Nacher M, El Guedj M, Vaz T, Nasser V, Randrianjohany A, Alvarez F, et al. Risk factors for late HIV diagnosis in French Guiana. AIDS 2005; 19:727-38.

2. Ferreira MP, Silva CM, Gomes MC, Silva SM. Testagem sorológica para o HIV e a importância dos Centros de Testagem e Aconselhamento (CTA) resultados de uma pesquisa no município do Rio de Janeiro. Ciênc Saúde Coletiva 2001; 6:481-90.

3. Kellerman SE, Lehaman JS, Lansky A, Stevens MR, Hecht FM, Bindman AB, et al. HIV testing within at-risk populations in the United States and the reasons for seeking or avoiding HIV testing. J Acquir Immune Defic Syndr 2002; 31:202-10.

4. Wright RJ, Stringer JSA. Rapid testing strategies for HIV-1 serodiagnosis in high-prevalence African settings. Am J Prev Med 2004; 27:42-8.

5. Medley A, Garcia-Moreno C, McGill S, Maman S. Rates, barriers and outcomes of HIV serostatus disclosure among women in developing countries: implications for prevention of mother-to-child transmission programmes. Bull World Health Organ 2004; 82:299-307.

6. Wilson SR, Brown NL, Chin V, Levin D, Kao Y, Hu P. Condom use by women recently diagnosed with a sexually transmitted infection. Sex Transm Dis 2004; 31:740-7.

7. Joint United Nations Programme on HIV/AIDS/ World Health Organization. AIDS epidemic update: December 2004. http://www.unaids.org/ wad 2004 / EPI_1204_pdf_en/Chapter 0 - $1_{-}$ intro_en.pdf (accessed on 15/Jan/2005).

8. Ministério da Saúde. Programa Nacional DST/ AIDS: Fique Sabendo, 2003. http://www.aids.gov. br/fiquesabendo/noticias1.asp?not=145 (accessed on $30 /$ Nov/2003).

9. Ministério da Saúde. Boletim Epidemiológico AIDS e DST 2004; ano I, n. 1. http://www.aids. gov.br/final/dados/BOLETIM2.pdf (accessed on 02/Dec/2004).

\section{Acknowledgments}

This study was conducted by the Universidade Federal de Minas Gerais with the technical and financial support of the cooperative project between the Programa Nacional de DST e AIDS and the United Nations Office on Drugs and Crime (UNODC), project no. AD/BRA/99/EO2).

10. Andrade TM, Dourado MI, Farias AH, Castroeu BG. Redução de danos e redução da prevalência de infecção pelo HIV entre usuários de drogas injetáveis em Salvador-Bahia. In: Teixeira PR, organizador. A contribuição dos estudos multicêntricos frente à epidemia de HIV/AIDS entre usuários de drogas injetáveis no Brasil: 10 anos de pesquisa e redução de danos. Brasília: Ministério da Saúde; 2001. p. 95-114. (Série Avaliação, 8).

11. Caiaffa WT, Bastos FI, Proietti FA, Reis ACM, Mingoti SA, Gandolfi D, et al. Practices surrounding syringe acquisition and disposal: effects of Syringe Exchange Programmes from different Brazilian regions-the AjUDE-Brasil II Project. Int J Drug Policy 2003; 14:365-71.

12. Hacker MA, Friedman SR, Telles PR, Teixeira SL, Bongertz V, Morgado MG, et al. The role of "longterm" and "new" injectors in a declining HIV/ AIDS epidemic in Rio de Janeiro, Brazil. Subst Use Misuse 2005; 40:99-123.

13. Caiaffa WT. Projeto AjUDE-Brasil. Avaliação epidemiológica dos usuários de drogas injetáveis dos projetos de redução de danos apoiados pela CN-DST/AIDS. Série Avaliação 6. 2001. http:// www.aids.gov.br (accessed on 20/Sep/2003).

14. Lwanga SK, Lemeshow S. Sample size determination in health studies: a practical manual. Geneva: World Health Organization; 1991.

15. World Health Organization/Joint United Nations Programme on HIV/AIDS. Second generation HIV surveillance: the next decade. Geneva: World Health Organization/Joint United Nations Programme on HIV/AIDS; 2000.

16. Hosmer DW, Lemeshow S. Applied logistic regression. New York: John Wiley \& Sons; 1989.

17. Shafer KP, Hahn JA, Lum PJ, Ochoa K, Graves A, Moss A. Prevalence and correlates of HIV infection among injection drug users in San Francisco. J Acquir Immune Defic Syndr 2002; 31:422-31. 
18. Cohen MS, Hosseenipour MC. HIV transmission: epidemiology, biology, and prevention. In: 9th Conference on Retroviruses and Opportunistic Infections; 2002. http://www.medscape.com/ viewarticle/430380 (accessed on 05/Sep/2005).

19. Centers for Disease Control and Prevention. HIV testing - United States, 2001. MMWR Morb Mortal Wkly Rep 2003; 52:540-5.

20. Zafar T, Brahmbhatt H, Imam G, Hassan S, Strathdee SA. HIV knowledge and risk behaviors among Pakistani and Afghani drug users in Quetta, Pakistan. J Acquir Immune Defic Syndr 2003; 32:394-8.

21. Tobin KE, Tang AM, Gilbert SH, Laktin CA. Correlates of HIV antibody testing among a sample of injection drug users: the role of social and contextual factors. AIDS Behav 2004; 8:303-10.

22. Riess TH, Kim C, Downing M. Motives for HIV testing among drug users: an analysis of gender differences. AIDS Educ Prev 2001; 13:509-23.

23. Spielberg F, Branson BM, Goldbaum GM, Lockhart D, Kurth A, Celum CL, et al. Overcoming barriers to HIV testing: preferences for new strategies among clients of Needle Exchange, a Sexually Transmitted Disease Clinic, and Sex Venues for Men Who Have Sex with Men. J Acquir Immune Defic Syndr 2003; 32:318-27.

24. Ramirez JR, Crano WD, Ousit R, Burgoon M, Alvaro EM, Grandpre J. Effects of fatalism and family communication on HIV/AIDS awareness variations in Native American and Anglo parents and children. AIDS Educ Prev 2002; 14:29-40.

25. Hopkins SG, Gelfand SE, Buskin SE, Kent JB, Kahle EM, Barkan SE. HIV testing behaviors and attitudes after adoption of name-to-code HIV case surveillance in Washington State. J Public Health Manag Pract 2005; 11:25-8.

26. Sullivan PS, Lansky A, Drake A. Failure to return for HIV test results among persons at high risk for HIV infection. J Acquir Immune Defic Syndr 2004; 35:511-8.
27. Downing M, Knight K, Riess TH, Vernon K, Mulia N, Ferreboeuf M, et al. Drug users talk about HIV testing: motivating and deterring factors. AIDS Care 2001; 13:561-77.

28. Lau C, Muula AS. HIV/AIDS in Sub-Saharan Africa. Croat Med J 2004; 45:402-14.

29. World Health Organization. " 3 by 5 ” progress report. December 2004 / WHO and UNAIDS. http:// www.who.int/3by5/en/ProgressReportfinal.pdf (accessed on 20/Aug/2005).

30. Szwarcwald CL, Júnior AB, Pascom AR, Júnior PR. Pesquisa de conhecimento, atitudes e práticas na população brasileira de 15 a 54 anos, 2004. Boletim Epidemiológico AIDS e DST 2004; ano XVIII, n 1.

31. Tapia-Aguirre V, Arillo-Santillán E, Allen B, Angeles-Llerenas A, Cruz-Valdéz A, Lazcano-Ponce E. Associations among condom use, sexual behavior, and knowledge about HIV/AIDS. A study of 13,293 public school students. Arch Med Res 2004; 35:334-43.

32. Spielberg F, Kurth A, Gorbach PM, Golbaum G. Moving from apprehension to action: HIV counseling and testing preferences in three at-risk populations. AIDS Educ Prev 2001; 13:524-40.

33. McGarrigle CA, Mercer CH, Fenton KA, Copas AJ, Wellings K, Erens B, et al. Investigating the relationship between HIV testing and risk behavior in Britain: National Survay of Sexual Attitudes and Lifestyles 2000. AIDS 2005; 19:77-84.

34. Cintra AMO, Caiaffa WT, Mingoti SA; Projeto AjUDE-Brasil. Characteristics of male and female injecting drug users of the AjUDE-Brasil II Project. Cad Saúde Pública 2006; 22:791-802.

35. Des Jarlais DC. Intoxications, intentions, and disease preventions. Sex Transm Dis 1997; 24:320-1.

Submitted on 24/May/2005

Final version resubmitted on 05/Sep/2005

Approved on 06/Sep/2005 